\title{
MYTH TO MAGIC: INTERACTIVE SYMBOLIC MAGMA-AN INTERVIEW WITH DR. MAUREEN ELLIS
}

\author{
Gül Esra ATALAY*
}

Myth to magic: Interactive symbolic magma-An interview with Dr. Maureen Ellis. Etkileşim, 8, 210-227. doi: 10.32739/etkilesim.2021.4.8.144

This study complies with research and publication ethics.

Bu çalışma araştırma ve yayın etiğine uygun olarak gerçekleştirilmiştir.

Due to COVID-19 related school closures, many countries have been exploring alternative ways to provide continuous education using technologies such as the Internet, TV, and radio. Education systems were unprepared for this transition. Schools and universities were forced to develop distance learning systems almost immediately. Dr. Maureen Ellis is a senior research associate at University College London and associate lecturer at The Open University, UK. She had given a keynote speech at $7^{\text {th }}$ International Communication Days at Üsküdar University in 2020 and the title of her speech was "Communication as Critical Global Semiotics". We spoke to Dr. Ellis about critical realism, critical global semiotics and education during COVID-19.

* Dr. Ellis, you were one of the keynote speakers of $7^{\text {th }}$ International Communication Days at Üsküdar University in 2020 and your interdisciplinary approach was very interesting and impressive for the audience. Would you tell us about yourself and your academic works?

Brought up in Bombay by loving parents, educated by dedicated British missionaries at a boarding school in the Western hills five hours away, mine was a naive magical faith in Go(o)dness and my mother tongue. As an AngloIndian, my community discounted our rich Indian 'her'itage, taking it for granted, identifying with British culture, Anglican tradition, English heritage. I only became aware of my Indian 'his'tory when I emigrated to Australia and married a member of the British Diplomatic Service. A myriad of Foreign Office postings merged a Master's in English Literature into a second MA in Applied

* Associate Professor, Üsküdar University, Faculty of Communication, gulesra.atalay@uskudar.edu.tr, ORCID: 0000-0002-3377-2694

210| ETKíteşim | Üsküdar Üniversitesi |iletişim Fakültesi |Akademik Dergisi 
Linguistics, and eventually an Unconditional Pass PhD at the Institute of Education (IoE), London University. Teaching in primary then secondary schools led to writing Teachers Manuals, alongside textbooks for students of English as a Foreign Language (TEFL) in the Middle East and China. Returning to the UK, I produced material for the University of Cambridge Local Examinations Syndicate, then Principles and Methodology MA modules at Oxford Brookes.

Unable to have children, my missionary fervour continued; each year for the next twenty or more years, I spoke at eight to ten conferences, overseas and in the UK. The beauty of travel, tourism, migration, in fact, any cultural exchange, even good fiction, is the opportunity to switch lenses, to align with alien mindsets, to adapt perspective, to empathise with different Other(s), to identify injustices at many levels. Sensitivity to, and love of language helps enormously in these first steps towards linguistic anthropology. For instance, travel to countries where the native language has no articles, laughing at the consequences of simple questions like 'What's time?' rather than 'What's THE time?' or 'Who's Queen?' instead of 'the Queen', awakens one to the importance of context, the imposition of an assumed shared understanding, and the advantages of what initially seems like a more philosophical consideration of Time, identity or power relations! Similarly, teaching English for Specific Purposes whether for Business, Medicine, Law, ... whatever, reveals distinctions obscured by mother-tongue assumptions, for example 'I like ...' versus 'I am like ...'; negative 'few' versus positive 'a few'; homophonic sun of man to anthropology's son of God; slippery prepositions and many more 'mysteries'.

One such revelation was the mathematical way 'Give me another' can mean 'more of the same' or Martin Buber's religiously existentialist 'Other'. Buber's 'Thou' derived from Sanskrit 'duo', meaning two, demonstrates, for $\mathrm{me}$, the risk of abstraction, as in merciful Lakshmi com-merc-ially dried, secular 'lucky'. Aristotle described logos as the appeal to reason. Having seen much political and theological manipulation in my travels, a conference in Devon entitled 'Global Citizenship' roused my interest and led to a part-time PhD at the IoE. Challenged by a question at $1^{\text {st-year }}$ presentations, I began attending lectures on Critical Realism (CR); meanwhile I continued teaching for the Open University. Mikhail Bakhtin's linguistic philosophy, CR's dialectical materialism, Franz Kafka's Systems theory, James Lovelock's Gaia, Michael Halliday's Systemic Functional Linguistics, a raft of Critical Theorists, Fairclough's Critical Analysis, homogenised vision and mission. In Carl Gustav Jung's use of the Indian concept of mandala or milk churn, 'milk of human kindness' turns into refined butter, rich creamy Sanskrit Khi/ghee.

Two rocky Upgrades sharpened my self-defence systems; pondering, licking one's wounds, is certainly a salve, and can yield valuable lessons. When one academic decried my submitted work as 'therapy', senior examiner Gunther

ISSN: 2636-7955 YII 4 Sayı 8 Ekim 2021 | ETKILEşiM | 211 
Kress, softened the blow, saying 'This is the work of someone who loves theory, and not just for this exercise, ...'. Later, wishing I'd used Jungian theory to counter the initial sneer, my (re)search continued and, to this day, relates entheos-iasm to theos, theory and therapy! I mention this to encourage readers to develop this wonderful habit of tracing linguistic metaphor, the spirit beyond words. In more theoretical terms, Bakhtin's 'stream of consciousness' or 'internally persuasive device' dynamically sustains self, amidst conflicting voices. When St Joan spoke of hearing voices, they stoned her as a witch; thank God today one can speak in these terms.

\section{* Critical realism is one of the main keywords of your work. What is critical realism and how did this field emerge?}

At the Institute of Education, London University, Critical Realism (CR) integrated many strands in my life. Brahmin physicist, World Scholar Roy Bhaskar's philosophical conviction of a realist ontology, a relativist epistemology, and a moral judgemental axiology reinstated individual consciousness, aatma, atomic energy, spirit as real. Jung's collective consciousness, zeitgeist, cultural host for life-long learning, confirmed Vygotsky's developmental 'zone of proximal learning' taking education beyond institutional walls; a Hindu relating individual atoms to collective atmosphere might phrase this 'Aatma is Brahma'.

Critical Realist philosophy is realised in Critical Discourse Analysis (CDA), a worthy methodology, providing we understand that 'discourse' is NOT just about language, but encompasses all communication. Logically, Critical Discourse skills should be taught by every academic; we all use language, so it makes sense for every use to be critically examined before messages are chewed, digested, and absorbed. 'Discourse' is 'this course', life itself. Discourse is about language, faith, belief, how we convert breath, theory, word (whether Bhagavatgita, Torah, Bible, Quran, GuruGranth, ...) into daily practice, everyday action. Discourse studies texts, in con-text, using a critical lens. The critique here is a constructive approach, identifying criteria that you consider crucial; somewhat like a doctor specifying criteria, explicitly demarcating, delineating distinctions before declaring a patient alive or dead. CDA leads citizens to ask who is setting the criteria, who's making the decisions, who benefits in this situation, who loses by this status quo? CDA helps us identify which voices, perspectives, points of view are being neglected in any account. CDA gives us tools to spot reliable and unreliable narrators in fact and/or fiction; you may remember I shared a handout about this at Üsküdar's 2020 conference.

Reading Roy's 'East to West: Journey of a Soul', revived my small Hindi, my smattering Sanskrit, igniting fresh dignity, sparking a passionate faith in etymology. Morris Halle's 'phonological and morphological distribution', well

212| ETKíleşim |Yıl 4|Sayı 8|Ekim 2021 
beyond my intellect, fired a trajectory into India's perennial philosophy, gospelling, gospelling 'common wealth'. Five CR concepts made satisfying sense, uniting the 'innocent' poetry and prose of my life. Though far better argued in 'The Critical Global Educator', I might say a bit about each here.

i. CR's Systemic worldview, configured as seven-chakra, seven pillars of wisdom, or seven concentric circles, represents striated, stratified reality (Archer et al., 1998: 659), with intelligence, snake-like Sapiente, working its way up the spine, from physical Being to metaphysical perfection. Whether drawn as sections of a triangle, nested circles, spirals or mobius strip, like Franz Kafka's Chaos Theory or James Lovelock's Gaia, ecological truth justifies Wittgenstein's claim, 'the limits of my language mean the limits of my world' (1922/2010). As paragraphs make way for comparative parallels, parables, parabolas, paradigms, paradise, French paradis fiscal, like Spanish paraiso fiscal expose powerful ideology. Eco-linguistics, wind as breath, expression, shuns partial namings of omniscient, omnipresent omnipotentiality which fracture humanity's historically-integrated giant beanstalk of knowledge. Sanskrit Om, roughly translatable as the music of the spheres, enables early access, heaven now, here, or nowhere. A positive anthropology posits faith, hope and love as theological virtues infused in human beings at birth, enabling us to dis-/ uncover, identify, define, find go(o)dness, divine DNA (Buber, 1958).

Professionals professing engagement in 'development' do well to remember the Sanskrit root 'dev' refers to Gods, divinity. Powerful ideologies, comprehensive frameworks like CR and SFS reveal potential roots, practical routes as God and human partnership. Physical/metaphysical Tao (dual/two) Ways forward deepen foundations, strengthen positions, confirm stance, enrich argument. Arg from Sanskrit 'aag' (fire) provokes an evolutionary search for meaning, as in the natural movement of a plant's leaves to sunlight or roots to water. Bakhtin's 'internally persuasive device' (Sanskrit dev/divine/ duo), thirsting after truth, seeks confirmatory evidence. Trans-disciplinary education, a thematic project approach, builds systemic understanding, meaningful semantics. Relating food to family and finance; climate to conflict and crime; human trafficking to arms trade and (un)Fair trade, the purpose of research becomes not merely to prove causal structures and relations, but to improve human freedom.

Systemic vision ensures Sanskrit 'hava' (wind), Judaic YHWH, venting, mission, and later commissions, address Ultimate Majesty, karmic Justice. Peirce's Final Interpretant (1908), Nirvana, no mere venting but awake to each fresh, purposeful breath allows Christians to phrase/frame 'thy kingdom come'. Such long-term reckoning anticipates implications and consequences across time and space, history and geography. Jewish Elohi, Abd-allah slaves submitting to ineffable I AM, One whose name must not be taken in vain (Ezekiel, 20:7), acknowledge go(o)dness today. Rather than postponing 
joy, John Lennon, one of the famous Beatles expressed this in his classic lyric, 'Imagine'. Systemic 'bildung' (German self-cultivation), working and walking midst great minds/spirits (Sanskrit Maha-aatma) prevents worship becoming warships as individual gain negotiates collective go(o)d. Eventually 'glocal' consciousness deftly merges international crime, intelligence, arms smuggling, drug trafficking, terrorism, money laundering, illicit financial flows, capital flight, debt to 'offshore' tax havens, as 'not only a place, a system and a process, it is also a collection of intellectual arguments' (Shaxson, 2012: 193), emergent physical/metaphysical h(e)avens.

ii. 3-Way Dialectical Materialism, like scientists' Dark Matter, affords powerful visual treatment of any semantic triangle or semiotic trinity. The thin wavy line balancing Taoism's yin/yang highlights creative potential, nuanced transitions between two extremes. The wavy middle line, serpent, sapiente, wisdom, marks individual or collective navigation between, negotiation, conversion between good/evil, tradition/innovation, poverty/wealth, comedy/tragedy, euphoria/dysphoria... any binary division. Applied to ancient or modern triumvirates- Brahma, Vishnu, Shiva; Father, Son and Holy Spirit; solids, liquids, gases; past, present, future - this shorthand heuristic allows open-ended, optimism. Shiva for instance is a powerful metaphor for death, destruction, but also cyclical ground, for instance re-forestation. Shiva is today worshipped by Hindus, Jews speak of Yeshua/Joshua and observe 'sitting Shiva' at a funeral, Quakers shiver before Mysterium Tremendum Mysterium Fascinans, phoneticians refer to the most common English sound schwa, but few appreciate how metaphors undergo change, resurrection, revival.

iii. Holism is today a concept deployed by theologians, scientists, theoretical and applied physicists, thanks to David Bohm's explaining consciousness, what I might call 'you'niverse, holography, holonymy, and early quantum theory. Bohm's (1980) 'Wholeness and the Implicate Order' confirms Mikhail Bakhtin's Biblical faith in 'word made flesh that dwells amongst us' (John, 1:14), a seminal text for linguists able to see the magnificent holographic power of words. Word, not literally as single sound, squawk, squiggle on a page, but word as expression, spirit, experiential light. Opticians talk of phoria, i.e. focused vision. Seeing human beings as metaphors, converting Promethean fire, disparate passions from dysphoria to euphoria, should make us very aware of metaphorization, how we use it, how others manage and manipulate us through their choice of metaphor. (W)holesome holistic approaches in Human, Life and Natural Sciences can potentially integrate our understanding, aligning work with self-worth and worship, everyday signs, science, consciences and consciousness. David Bohm's work inspires mathematicians, scientists, musicians, theologians and semioticians to collaborate across linguistic barriers.

Renewed respect for metaphoric power, prismatic word, leads to constant 214| ETKileşim |Yıl 4|Sayı 8| Ekim 2021 
scrutiny of all constructive and destructive energy; references to space and time, preferences of 'our' and 'we' are no longer taken-for-granted 'virgin assumptions'. As Basil Bernstein (1996:24) noted, 'Every time a discourse moves, there is space for ideology to play'. Deixis we daily, naturally, adopt in 'my school', 'my country', now/tomorrow, here/there, bring/take, ... are appropriations sanctioned by convention, assumed proprietorial rights and deictic powers worth pondering. Deictic complementarity, deification, 'primordial, anterior and more fundamental than any other linguistic function' (Kirtchuk, 2008: 35) become open to analysis and review. Even the very profusion of 'water metaphors' which represent and nourish human 'streams of consciousness', if /when contemplated, can refresh respect and treatment of the 'environment' which geneticists interpret in 'terms and conditions' going back far further than most of us.

iv. Bakhtin's term for the different voices around us was 'heteroglossia', i.e. many tongues. This is not only true in life but, in any text, you can see whose voice or point of view is being presented, whose perspective is being expressed, whose interests are being neglected, ignored, or silenced. Heteroglossia also points to diverse genre and sub-genre, the many ways, multiple modes, or multimodality of being, having and doing across the globe, various languages, disciplines, cultures, geographies... Consideration of the many stake-holders, not merely shareholders in any project confirmed my global experience of voice and vocation.

Michael Halliday provided practical analytical tools that semioticians like Gunther Kress extended to colour, music, song, dance, gesture, ritual, and daily performance. So we had analytical tools for various modes and the media which are used to spread ideology, such as newspapers, radio, TV, film and sophisticated technology.

v. My fifth encouraging CR concept was Bhaskar's Transformational Model of Social Activity, faith in eudaimonia, good spirits in collective transformation. International non-governmental organisations had shown how training teachers helped convert personal transformative experience to professional transactions and political transformation. Theory spelt vital empowerment, shifting personal politeness to confident, efficacious policy critique. Academics teaching global citizens to play what Wittgenstein describes as 'language games', distinguish literary representational re-presentations from referential, reverential citation. Transparency International, Tax Justice Network, CGE, later even CGS demand financial transparency as spiritual power to make transparent causal effects. Today International Consortium of Investigative Journalists collaborations produce the Panama Papers, Pandora Papers, and FinCen files, exposing off-shore financial crime; the misuse of solitary confinement by United States immigration authorities; human rights abuses in China; failure of the medical device industry. 
Empirical evidence involving questionnaires and scripted interviews with over 500 participant teachers, teacher-trainers, NGO administrators and academics, used Yrgo Engestrom's Cultural Historical Activity Theory (CHAT), an excellent framework I would recommend to researchers investigating transformative growth. The Routledge publication of 'The Critical Global Educator' (2016) reported eight recommendations based on this research. Transformed consciousness mystically integrates, 'absorption of the Divine in nature' (Buber, 1958: 145). 'He who truly goes out to meet the world goes out also to God' (ibid, 95), to 'realiz[e] the divine truth in the fullness of everyday life' (ibid, 195) where 'everything is waiting to be hallowed by you' (212).

\section{* How do critical realism and critical semiotics intersect?}

CGS confirmed my intuitions of conceptual congruence between CR emergence to human flourishing, and Peirce's (CP 8.314 and 8.315) semiosis of evolving final interpretants: CR's Aletheia and Semiotics' Tyche as reality unaffected by human thought; rationality as Peirce's pragmaticist reasonableness and Bhaskar's concrete universal; Peirce's pragmaticism and Bhaskar's interdependence of facts and values. Roy Bhaskar's Critical Realism relied on ancient Vedic, Taoist, Buddhist foundations for philosophic systemic ontology; Charles Sanders Peirce, generally seen as the father of Semiotics develops more recent Greek interest, expanding the critical focus on language to include all signs and symbolic interpretation. Ancient CR wisdom and SFS pragmaticism combine resources for political cohesion in critical discourse analysis.

While CR ontology may be presented as a differentiated, stratified, laminated pyramid, Peirce's three interactive Universes of Phenomenology, Science and Socio-linguistics, semiotically merge Icon, Index and Interpretant in complex maelstrom reality. While CR may portray reality in layers from physics, chemistry, biology, socio-politics and economics right up to the moral and ethical realms, and CDA may treat each in terms of genre and sub-genre, Semiotics might analyse these layers more finely in terms of semiotic domains (cyto-, bio-, zoo-, ....) and sub-domains (proto-, necro-, and endo-).

Yet there are similarities too; both require trans-disciplinary collaboration in the search for Ab-solutions! We can trace a history of ideas in anthropologically rich CR and CGS approaches: The Sanskrit Khi, carried by Buddhist texts becomes the Greek Goddess Tyche (touch), Peirce's First universe, representing Chance, Spontaneity, Intuition. Taoist Taichi has the figure 8, lying on its side, representing human and cosmic interaction, as in Michelangelo painting on the Sistine Chapel, with God reaching down to touch Adam's outstretched finger. Worth noticing here is the female previously held in the Almighty's left arm, before the feminine principle was replaced by a patriarchal society.

216| ETKíleşim |Yıl 4|Sayı 8|Ekim 2021 
What is important is that both CR and Systemic Functional Semiotics are looking at complex transitions, reality as transformational process, rather than static product. The tripartite consideration is Product via Process, but always questioning Purpose. This means both frameworks allow for development in positive, optimistic terms, with an important role for human understanding, agency and creativity. Both begin with the individual, CR's 'concrete singular', and Peirce's 'qualisign' and 'sinsigns'. CR processes rely on human 'positions and practices' while Semiotics studies this evolving process as synechism, contiguity, evolving immediate versus dynamic 'objects' and 'interpretants'. Both conjure human progress towards perfection, Bhaskar in terms of 'universal human flourishing', Semiotics in mediated movement to a Final Interpretant. While CDA provides conceptual and practical tools for analysis, semiotics offers Peirce's ten categories, capable of various combinations. Julian Algirdas Greimas' actant analysis, semiotic square, and modalised trajectory of signification help us track these emerging processes, as abstract nouns epitomise common, collective, proper, even pro-nouns, up and down Jacob's (metaphoric) Ladder. Concrete human universals 'texture' being to wanting and doing; virtuality/potentiality to actuality and reality; desire to competence and performance. Enonce/announcement/annunciations (Greimas, 1976) fabricate or transfigure immanent noumena to manifest phenomena.

\section{*What is the relevance of "critical semiotics" and "critical realism" in the age of digital media?}

Both critical realism and critical semiotics prepare citizens with practical tools to analyse multimodal discourse: the many 'languages' of Arts, Sciences, Humanities; national languages; heteroglossic 'tongues' of multitudinous arts and crafts. The wonderful potential of digital media is the accessibility of the best teachers, resources, ideas shared with ease; even poor, remote learners can enjoy world-standard libraries, art galleries, museums if equitable laws nuance copyright regulation. Critical digital skills, strategies, techniques, can be taught from kindergarten to university level. Habituated from an early age, critical lenses in every discipline shape discipleship, subjectivity, apprenticeship, the way we apprehend the world. Critical thinking forms Aristotelian hexis, Bourdieu habitus, colouring our worlds, influencing tastes, moods and modes of being, having and doing, in Semiotics' immediate and dynamic terms. As intermediaries, mindful of media and our own intermediary functioning, morality and religion are no longer insular subjects on a Friday afternoon, or Sunday morning, i-soulated from society and weekday pursuits. Art classes, music lessons, cookery clubs, science laboratories become enriched by cross-cultural curricula open to rational debate, discussion, evidence and justification. Open University's OpenLearn, and Professor Sugata Mitra's 
School in the Cloud and Granny Cloud projects at Newcastle University, are good examples of fair digital access which aims to release critical creativity, Tyche spontaneity, chance, intuition, Peirce's 'musement'.

Oscillating between chaos and control, Freedom of Information and Data Protection, pure play lends itself to creative hypotheses, abduction later open to verification - 'the idea of putting together what we had never before dreamed of putting together (an idea) which flashes the new suggestion before our contemplation' (CP 5.181). Neuro-scientists refer to this 'default mental network' (DMN), as internal dialogue of ideas and images, activated by internally focused tasks such as autobiographical memory retrieval, envisioning the future, and conceiving the perspectives of others. The DMN operates using multiple interacting subsystems of the brain, importing, impacting, integrating converging nodes, connecting regions of brain cells normally 'too busy to communicate'. Synergy, synechism, chiasma beyond isolated logics or specific sciences, metaphysically grow reasonableness. Peirce's mystic 'musement' (CP 6.455, 1908) aesthetically mediates, harmoniously reconciles, sense and reason. Linking individual micro- with lofty macro-cosmos, musement connects Peirce's (1908) three universes of experience, brute actuality, and signs in unlikely ways, conducive with ideas of the 'reality of God'.

\section{* How do these two concepts intersect with communication and interaction?}

Understanding psyche (Greek for soul), individual and mass psychosis, as search for Herculean redeemer personality, psychotherapist Carl Gustav Jung used word association, talk remedy, today's cognitive behavioural therapy. Drawing on travels in India, Africa, correspondents in China, he explained human development, illusion, distortion, delusion, through memories, dreams and reflections. Anthropologically tracing the history of ideas, i-deal absorption, 'individuation', Jung discerned Eastern wisdom as collective unconscious heart of Western consciousness.

Only this East is not a Tibetan monastery full of Mahatmas, but in a sense lies within us. It is from the depths of our own psychic life that new spiritual forms will arise; they will be expression of psychic forces which may help to subdue the boundless lust for prey of Aryan man (Jung, 1933: 221).

Defining 'faith' as self-to-Self realisation, trust in and loyalty to the God with/in, Jung relied on intertextual interdenominational dialectics. Uncertain whether to direct 'many well-educated patients' to the psychotherapist or clergyman, to heal 'the warring halves of the personality' (244), he concludes: 'The living spirit grows and even outgrows its earlier forms of expression; it freely chooses the men in whom it lives and who proclaim it. This living spirit is eternally renewed and pursues its goal in manifold and inconceivable ways

218| ETKileşim |Yıl 4|Sayı 8|Ekim 2021 
throughout the history of mankind. Measured against it, the names and forms which men have given it mean little enough; they are only the changing leaves and blossoms on the stem of the eternal tree'.

Socio-psychologist Erving Goffman (1969), a Canadian socio-psychologist working in casinos and asylums, with gamblers, schizophrenics and death-row prisoners, also understood mental suffering, crime, gambling, and suicide. Word as sacramental magma, universal semiotic material of inner life, means 'we repeat, when discourse is torn from reality, it is fatal for the word itself as well; words grow sickly, lose semantic depth and flexibility, the capacity to expand and renew their meanings in new living contexts' (Bakhtin, 1991: 353). Relating personal psychological self (identity/frames/face) to public sociological self (position/footings/status), Goffman's work confirms that con-fidence (literally, with faith) depends on self-esteem, inner coherence, steam with/in Bakhtin's stream of consciousness. Literal words as empty signs represent text devoid of context, prison rather than prism. A logocentric love of language liberates metaphoric word-power relating token to type, source to target, material to ethereal, mother's care to father's 'busyness'. Ability to decipher metaphor gifts humanity with super-vision, vital physical and metaphysical integrity.

\section{* We have been facing a global pandemic for the last one and half years. This has been a hard period for everyone, yet it is a phase of transformation for the field of education. As an academic on educational studies, how do you evaluate education during the pandemic?}

Human intelligence can convert any curse into karmic cause for advancement. Pandemic dynamics have drastically altered several domains from education, tourism and healthcare, to industry, trade and politicstesting communication and digital skills, modes and media we've taken for granted. Even the simplest technologies, tools, 'texts' of everyday exchange - door handles, pens and bank cheques, trolley hand rails have been raised to conscious con-textual concern! Bacteria, most primitive life forms, witless virus, threaten the wit of humankind. Enforced telemedicine, online optical, physio and dental care, distance education oblige handicapped Luddites like $\mathrm{me}$, to channel aspiration. Unfamiliar silences allow separation of urgent from important matters; soul-searching i-solation can mean time to contemplate I-deals, to un-cover spiritual values, even perhaps to discover fresh 'conspiracy'. Some academics, helped by Open University expertise, have devised hybrid methods; in my case, unable to enjoy an office in London, direct access to library resources, stimulating conferring and conference, the IoE use of Microsoft Teams, Zoom's Chat facility, and researching 'Myth, Metaphor, Magi(c)' praxis help raise me, mess, message to messiahship! 
In 1867, theoretical physicist James Clerk Maxwell, described a thought experiment, later referred to by Lord Kellner as 'Maxwell's Demon'. This thermodynamic model 'demon'strated g(o)od and (d)evil, CR's dialectical materialism, Taoist yin/yang. Contradictions will always be with us, but for those scientific consciences that understand physics, electro-magnetic energy, changing forms, neural oscillations, empathic vibrations, community, trusting communication, comm-union 'as one', can overcome emerging, persisting dissonance.

'Universe-cities', living laboratories, re-presenting and challenging universal values, expose the disastrously flawed logic of severing citizens' 'literacy' and 'media studies' from active/action research (Weber and Duderstadt, 2012). Freedom to contradict and contest policy, to speak one's 'truths' on climate change, bio-diversity, human, animal and environmental rights, demand evolutionary beta-gamma scientific consilience (Wilson, 1998).

As academics, we must be sure that results we deliver, PhDs we confer, research 'subjects' funded, genomic data selected, Artificial Intelligence algorithms promoted generate genius and genre which address global issues rather than narrow national interests, short-term gains, selfish genes. Understanding the social construction of curriculum, the academic jousting for status, resources, funding, means the pandemic offers academics a chance to collaboratively reset transdisciplinary balance, nesting Jungian anima, animations, humanitarian Politics and natural Sciences with/in universally sound policy (Teilhard de Chardin, 1965).

\section{* I feel fortunate and delighted to be part of your book Critical Glob- al Semiotics: Understanding Sustainable Transformational Citizenship (CGS.) Would you tell us about this international and interdisciplinary book project?}

Applied linguists treat each discourse field as language in action, social practice, everyday performance merging implicit faiths with explicit beliefs. Put simply, Semiotics is the science of signs, how meaning develops, the gradual formation of symbols. It adopts Wittgenstein's view of human endeavour as so many domains, each with its own semantics/vocabulary (paradigms, material and human resources, component structures) arranged in a syntax/ grammar(syntagms, procedures, routines).CGSdemonstratestransformational logogenesis, crucial driver of logocentric anthropology. Aristotle's phronesis, the application of universal principle to particular, Bourdieu's practical wisdom, even Peirce's synechism, stripped of disconcerting terminology, can be made accessible to citizens at an early age through everyday synecdoche, meronymy, and metonymy. 
In 'Critical Global Semiotics: understanding sustainable transformational citizenship' (CGS), 24 authors from 13 countries applied two frameworks I'd elaborated in 'The Critical Global Educator' to 16 disciplines. Drawing on Anthropology, Architecture, Cultural Studies, Feminism, Film, Health, Law, Linguistics, Anthropology, Management, Media, Performing Arts, Pharmaceuticals, Politics, Sociology, Sustainability Education, and Urban Development, the 16 chapters reflected perspectives on/from Australia, Brazil, China, France, India, Iraq, Italy, Mexico, Rwanda, South Africa, Turkey, the UK, and the USA. Analysts used Michael Halliday's Systemic Functional Linguistics, practical frameworks extended to Multimodality, a branch of semiotics developed by Gunther Kress and others.

Dr. Atalay, Assistant Professor of Sociology and Sociology of Communication at Üsküdar University Faculty of Communication, one of the authors in Critical Global Semiotics, wrote on commercially-generated myths in 'Newage child labour in Turkey: child influencers on YouTube'. As Robert Yelle (2016) explains:

Semiotics does not presume any absolute qualitative difference between religious and other phenomena. (...) Semiotics is as much the study of culturally effective illusions as the key to a universal science of communication. Or perhaps it must be both at the same time... semiotics has the potential to serve as a useful rubric for describing the differences (as well as similarities) between cultures, and to contribute to our understanding of the historical transformations grouped together under the label of 'secularization'.

Reliant on cultural memory, artefacts nestle texts into con-text, consciously or unconsciously, intuitively valued before critically evaluated. Nietzsche's 'God is Dead', like Barthes' 'Death of the Author', simply reiterate readers' independent interpretation. Connotation based on word associations within coded iconic messages, intentionally or unintentionally convey covert concepts (Barthes, 1964). Infectious social media, powerful imaginations, magically de-sign word and image, verbal weight and visual charge spark good/evil impulsive transformation. Accepting that plurality in society admits space for deliberative democracy (Habermas, 1984), Dr. Atalay identified legal lacuna: inadequate laws controlling the use of children in advertising, the cancer of consumerism, and environmental damage. Poor media literacy, absent factchecking skills, ensure this dangerous synthetic veneer of neutrality, freedom, even joyful exuberance, escapes scrupulous scrutiny of media, mediators and intermediaries.

As global conflicts escalate, cognitive-, neuro-, psycho-, and sociolinguistics reveal pre-conceptual limbic emotion which governs myth, metaphor, schematic assumptions, linguistic presuppositions. Another author in CGS, Dr. Victoria Lindsay, writing from the British Council in Iraq, also dealt with global issues originating in the Middle East. Using computer technology for corpus 
analysis of Iraqi discourse on 'countering' and 'preventing' violent extremism, she noted a generative absence of discussions which directly register 'education within the context of a key radicalisation driver' and 'a curious lack of focus on another frequently cited driver - unemployment'. '[H]ostile malevolent' portrayals have implications for 'both the Iraqi and international community'. (W)holistic, nondual 'at-one-ment' crosses divide as individuals re-cognise urgent global concerns. Lindsay's logocentric focus noted 'the development of an elitist lexicon of countering violent extremism phrases which has been developed, but not widely shared, by those working in policy and programming', as Bakhtinian addressivity, artful inclusive or exclusive tailoring of content which aligns or alienates.

CGS has many fascinating chapters from dance and music to global education, urban development, Big-pharma, and political-economy. A wide variety of analytical frameworks are demonstrated and an open-access free online website supplements the book.

\section{* What topics will your latest project "Myth, Metaphor and Magi(c): Consciousness, conSciences, spirituality" discuss?}

Tower of Babel limitations steer multiple intelligences to choose from the philosopher's 'love', the engineer's 'power', the scientist's 'energy', the sociologist's 'beliefs', the artist's 'beauty', the poet's 'truth', the religious' 'faith'. 'The scriptures are a form of mythos which have been misread for centuries as works of logos or history' (Tacey, 2015). Former Catholic priest Crossan states:

My point is not that those ancient people told literal stories and we are now smart enough to take them symbolically, but that they told them symbolically and we are now dumb enough to take them literally. They knew what they were doing; we don't (Crossan and Watts, 1996: 79).

Understanding metaphors -ontological, structural, or orientational importcan help us navigate uncharted waters of consciousness. String theory, force fields, bull and bear markets affirm imagery, imagination, metaphor a-'cross' disciplinary borders. Yet today there are those manipulated to take literally 2,000-year-old messages, modified across languages, times, climes. Citizens 'catching the bus', 'taking the last train home', en-theos-iastically exclaiming 'I see what you mean', sincerely desirous of 'turning to God', should not be left to 'figure' out this metaphoric ubiquity.

Explaining the essentially metaphoric nature of thought, language, and development, cognitive linguists Lakoff and Johnson (1980: 196-197) link surface frames to deeper conceptual root metaphors, demonstrating that "most of the conceptual structure of a natural language is metaphorical", 
around $90 \%$ in some datasets. Like sacred Greek amphora, metaphors store and secrete precious defining aphorisms, proverbs, idioms, wise sayings, stories, jokes, secrets that linger in hearts and minds. Activating imagination, cascading myth, memory and emotion, sensory and motor nerves, neuronal assemblies, drive future perception for better or worse. Kant (1781: 182) explains "the schematism of pure understanding. (...) The schema is in itself always a product of pure imagination". Experience, concepts, mind, Kant's 'blind but indispensable function of the soul', 'always stan[d] in immediate relation to the schema of imagination, as a rule for the determination of our intuition, in accordance with some specific universal concept'.

Jung's (1933) anthropological studies show that just as the human body relates to earlier life species, 'so the human psyche is likewise a product of evolution, which when followed up to its origins shows countless archaic traits'. Human imagination spells apophatic spiritual communication beyond word and image. While talk therapy articulates dreams and nightmares, Jung's concept of a 'collective unconscious' merges memories, myth, and metaphor. Studying modern man's Genesis-to-genetics search for a soul, Jung asserted it was no longer possible, necessary, nor beneficial, to read the Bible literally.

As the highest value and supreme dominant in the psychic hierarchy, the Godimage is immediately related to, or identical with, the self, and everything that happens to the God-image has an effect on the latter. Any uncertainty about the God-image causes a profound uneasiness in the self, for which reason the question is generally ignored because of its painfulness. But that does not mean that it remains unasked in the unconscious. ... Stagnation in these matters is threatened in the long run with a lethal end (Jung, 2014: 109).

Metaphysical, metaphorical processes - conception, transfiguration, resurrection - transpire in the imagination, sound magnetic potential, resonant image of God (Genesis 1:26). Peirce's three universes also begin with individual phenomena, qualia sensations altering perception and prompting conception, moving individual oscillations to collective vibrations, consolidating spiritual forms (Abraham, 2021).

Open to dialectic discernment, discussion, discrimination, "second edge of consciousness" (Williams, 1983), critical realists consider fundamentalist literal second comings - dreamlike, dramatic or traumatic - frustrating obfuscation. Ancient hermits, today's Hermes, messengers of G(o)od critical faculties must collectively interpret symbolic magma, textualization. Con-textual hermeneutics differs from immediate exegesis, the former taking account of technological developments which consequently alter/altar meaning, connotation and implication (Barthes, 1972).

Academics who neglect trans-disciplinarity fracture incense/inner sense; meanwhile, neuro-immunologists (Nutma et al, 2019) seek the holy grail of consciousness, 'miracle' cross-border phenomenological/psychological 
brain-wave/Way from 'hellth' to h(e)aven, healing, health. Neuro-scientist Susan Greenfield (2017: 2) questions what would satisfy: "So what would actually prove to you that some scientist, or philosopher, or even scifi novelist, had come up with the definitive insight into the subjective experience we call consciousness?". Global citizenship entails synechistic life-long learning, metaphoric milk-churn, mandala. (W)holistic psychology (Jung, 1965), grounded in CR's concept of the stratified embodied self, used memories, dreams, reflection and active imagination to recover Self, selfconscious participation in Soul, S-pirit o-f U-nconditional L-oving. Discovering metaphoricity, expanding spirit, citizens achieve equilibria, wisdom with/in environmental constraints, magi(c). No longer mere cognitive abstraction, metaphorization as process articulates socially embedded, embodied dynamics, ecologically enacted and extended.

Acknowledging the power of myth, this project will I hope dispel divisive, harmful myth, and raise awareness of our own capacity as spry metaphoric sprites to transform Jesuit palaeontologist Teilhard de Chardin's (1955) Christic to what I term Krishtic consciousness. Incorporating spirituality with/in scientific search, these authors may light and enlighten paths, from rites to righteousness, sanity to sainthood. The magi are symbols in the Christmas myth, wise astronomers in a story about stability, status quo, and the way simple and powerful humanity respond to the novel. Representative voices of various denominations will explore con-sciences today: neuro, natural-, human-, socio-political, panpsychic, panentheistic... mystic physicist David Bohm's 'wholistic' model of reality, totality of matter and consciousness. Cosmological metaphysics, Vedic Rta, Greek Arete, Promethean fire, excellence approaching the Ancient of days, Hebrew Eloh, Islam's Allah, One whose name must not be taken in vain demands epistemic humility, awe, and wonder. Anticipating Quantum Consciousness, subtle 'holomovement', implicit/explicit reverberations, 'active transformations' enfolding / unfolding wholeness, Bohm (1980: 198) explains, "The question of whether you want to call it God depends on what you mean by the word" (2013).

\section{References}

Abraham, R. (2021). Vibrations and forms. New York: Epigraph Publishing Service.

Archer, M., Bhaskar, R., Collier, A., Lawson, T. and Norrie, A. (eds.) (1998). Critical realism: Essential readings. London: Routledge.

Bakhtin, M. M. (1991). Dialogic imagination: Four essays by M. M. Bakhtin (C. Emerson and M. Holquist, trans.). Austin, TX: University of Texas Press.

Barthes, R. (1972). Mythologies (A. Lavers, trans.). New York: The Noonday Press.

Bernstein, B. (1996). Pedagogy, symbolic control and identity. London: Taylor \& 
Francis.

Bhaskar, R. (2000). From east to west: Odyssey of a soul. London: Routledge.

Bohm, D. (1980). Wholeness and the implicate order. London: Routledge and Kegan Paul.http://www.gci.org.uk/Documents/DavidBohm-WholenessAndThelmplicateOrder.pdf. 6 September 2021.

(2013). "Art Meets Science and Spirituality in a Changing EconomyFrom Fragmentation to Wholeness". Amsterdam 1990. https://www.youtube. com/watch?v=mDKB7GcHNac. Transcript: https://creativesystemsthinking. wordpress.com/2014/10/01/wholeness-a-coherent-approach-to-reality-davidbohm/. 6 September 2021.

Buber, M. (1958). I and Thou (R. Gregor-Smith, trans). Edinburgh: Clark.

Crossan, J. D. and R. G. Watts (1996). Who is Jesus: Answers to your questions about the historical Jesus. Louisville Kentucky: Westminster John Knox Press.

Engestrom, Y. (1987). Learning by Expanding: An activity-theoretical approach to developmental research. http://lchc.ucsd.edu/mca/Paper/Engestrom/expanding/ ch1. htm.25 February 2015.

Ezekiel 20:7, Holy Bible: King James Version.

Fairclough, N. (2010). Critical Discourse Analysis: The critical study of language (2nd edn). Harlow, UK: Pearson.

Goffman, E. (1969). The presentation of self in everyday life. London: Penguin

Greenfield, S. (2017). A day in the life of the brain. Penguin Books Ltd. Kindle Edition.

Greimas, A. J. (1976). On meaning: Selected writings in semiotic theory (P. J. Perron and F. H. Collins). F. H. Minneapolis: University of Minnesota.

Habermas, J. (1984). The theory of communicative action. Volume I: Reason and the rationalization of society and volume II: Lifeworld and system: A critique of functionalist reason. Boston, MA: Beacon Press (originally published 1981).

Halliday, M. (1985). An introduction to functional grammar. London and Baltimore: E. Arnold.

Jaffe, A. (1979). C. G. Jung: Word and image. Princeton, NJ: Princeton University Press.

John 1:14; Holy Bible: King James Version.

Jung, C. G. (1933). Modern man in search of a Soul. Abingdon, UK: Routledge.

(1965). Memories, dreams, reflections. New York: Vintage.

(2014). Aion: Researches into the phenomenology of the self. $2^{\text {nd }}$ (R. F. C. Hull, ed. and trans.). London: Routledge.

Kirtchuk, P. (2008). 'LUIT: Language, a unifi ed and integrative theory'. https://hal. 
archives-ouvertes.fr/hal-00545240v6/document. 17 June 2019.

Lakoff, G. and Johnson, M. (1980). Metaphors we live by. Chicago, IL: University of Chicago Press.

Nutma, E., Willison, H., Martino G. and Amor, S. (2019). Neuroimmunology - the past, present and future. Clin Exp Immunol, 197(3), 278-293. doi: 10.1111/ cei.13279. Epub 2019 Mar 11. PMID: 30768789; PMCID: PMC6693969.

Peirce, C. S. (1908). 'A neglected argument for the reality of god'. http:// en.wikisource.org/wiki/A_Neglected_Argument_for_the_Reality_of_God. 15 May 2019. Originally published in 1908 in Hibbert Journal, $\overline{7}(1), 90-112$, Internet Archive.

(1931-1958) [1860-1913]. Collected papers, vols. 1-8. (C. Hartshorne, P. Weiss and A. W. Burks, eds.). Cambridge, MA: Harvard University Press.

Shaxson, N. (2012). Treasure islands: Tax havens and the men who stole the world. London: Vintage.

Tacey, D. (2015). Religion as metaphor: Beyond literal belief. London: Transaction Publishers/Routledge.

Teilhard de Chardin, P. (1955). The Christic. Global Net. http://www.users.globalnet.co.uk/ alfar2/Christic.htm.18 April 2021.

(1965). Hymn of the universe. New York: Harper \& Row.

Weber, L. E. and Duderstadt, J. J. (2012). Global sustainability and the responsibilities of universities. Paris: Economica.

Williams, R. (1983). Keywords: A vocabulary of culture and society (2nd edn). London: Fontana (originally published 1976).

Wilson, E. O. (1998). Consilience: The unity of knowledge. New York: Alfred A. Knopf.

Wittgenstein, L. (1922/2010). Tractatus logico-philosophicus logisch-philosophische Abhandlung. London: Keegan Paul. (Side-by-side-by-side edn, Version 0.21, published 2010, containing original German, alongside both the Ogden-Ramsey, and Pears-McGuinness English translations).

Yelle, R. A., (2016). 'Semiotics', M. Stausberg and S. Engler (eds.) The Oxford handbook of the study of religion. www.oxfordhandbooks.com.libproxy. ucl.ac.uk/view/10.1093/oxfordhb/9780198729570.001.0001/oxfordhb9780198729570-e-15. 
Figure 1. The critical global educator

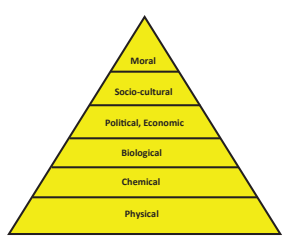

The Critical Global Educator

Global Citizenship Education as Sustainable Development
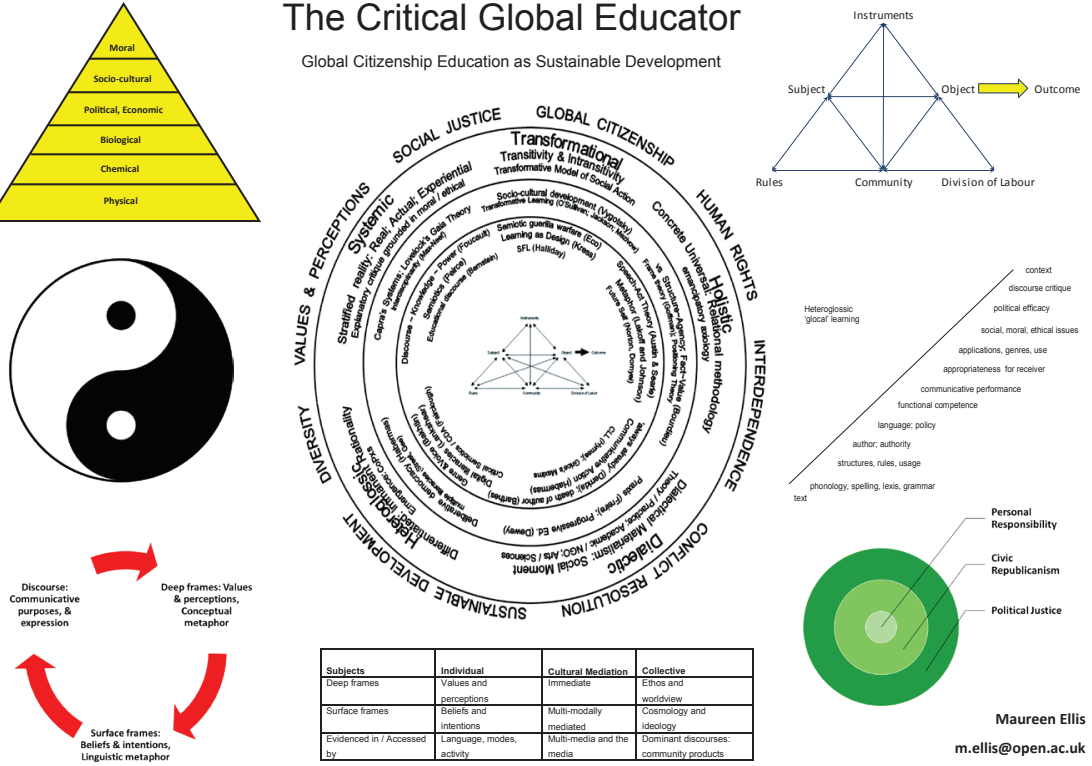

Conflict of interest: There are no conflicts of interest to declare.

Financial support: No funding was received for this study.

Çıkar çatışması: Çıkar çatışması bulunmamaktadır.

Finansal destek: Finansal destek bulunmamaktadır. 